\title{
New Ceramides from Acnistus arborescens
}

\author{
Ana Isabel V. Maia, ${ }^{a}$ Maria Leopoldina Veras, ${ }^{a}$ Raimundo Braz-Filho, ${ }^{a}$ \\ Norberto P. Lopes, ${ }^{b}$ Edilberto R. Silveira ${ }^{a}$ and Otilia Deusdênia L. Pessoa*,a \\ ${ }^{a}$ Departamento de Química Orgânica e Inorgânica, Centro de Ciências, Universidade Federal do \\ Ceará, CP 12200, 60021-970 Fortaleza-CE, Brazil \\ ${ }^{b}$ Departamento de Física e Química, Faculdade de Ciências Farmacêuticas de Ribeirão Preto, \\ Universidade de São Paulo, 14040-903 Ribeirão Preto-SP, Brazil
}

\begin{abstract}
Duas novas ceramidas $N$-(4-hidroxifeniletil)octacosamida (1) e rel-(2S,3S,4R,16E)-2-[(2' $R$ )2'-hidroxinonadecanoilamino]-heneicosadec-16-eno-1,3,4-triol (2) foram isoladas do extrato etanólico de Acnistus arborescens. As estruturas foram elucidadas por métodos espectroscópicos (experimentos de RMN 1D e 2D, EMAR com ionização por electrospray, EM e IV).

Two new ceramides, $N$-(4-hydroxyphenethyl)octacosamide (1) and rel-(2S,3S,4R,16E)-2[(2'R)-2'-hydroxynonadecanoylamino]-heneicosadec-16-ene-1,3,4-triol (2) were isolated from the EtOH extract of Acnistus arborescens. The structures were elucidated by spectroscopic (1D and 2D NMR experiments, HR-ESI-MS, LR-MS and IR) methods.
\end{abstract}

Keywords: Acnistus arborescens, Solanaceae, ceramides

\section{Introduction}

The genus Acnistus (Solanaceae) comprises 50 tropical American species of shrubs and small trees distributed from Mexico to Southern Argentina. ${ }^{1}$ Plants of this genus biosynthesize a complex group of natural $\mathrm{C}_{28}$ steroidal lactones, known as acnistins, ${ }^{2}$ withanolides,${ }^{3}$ and jaborols. ${ }^{4}$ As part of a collaborative search program to identify novel naturally occurring anticancer agents, we have investigated Acnistus arborescens (L.) Schlecht. ${ }^{5,6}$ The plant presents different therapeutic uses in the traditional medicine, for instance, the hot infusion of leaves and barks is used in the treatment of bruises and sprains, moreover, the leaves have been used to treat liver and spleen diseases, and cancerous growths. ${ }^{1,7,8}$ Indeed, previous studies on this species have led to the isolation of several cytotoxic withanolides. ${ }^{7,8}$ Recently, it was published for the first time the isolation of withaphysalins, including its cytotoxic effects against several tumor cell lines. ${ }^{5,6}$

In this paper, the isolation and characterization of two new ceramides from $A$. arborescens is described. This is the first examples of ceramides from a plant of the Acnistus genus and, to the best of our knowledge, the second

*e-mail: opessoa@ufc.br report about such kind of secondary metabolites from the Solanaceae family. ${ }^{9}$

Ceramides and related compounds have been isolated extensively from fungi ${ }^{10}$ and several marine organisms such as sponges, ${ }^{11}$ tunicates, ${ }^{12}$ sea stars, ${ }^{13}$ green algae ${ }^{14}$ and gorgonians. ${ }^{15}$ However, more recently, this class of compound has been isolated from some higher plants. ${ }^{9,16-18}$

\section{Results and Discussion}

The EtOH extracts from leaves and stems of A. arborescens were fractionated by column chromatography on silica gel by elution with $n$-hexane, $\mathrm{CH}_{2} \mathrm{Cl}_{2}$, EtOAc and $\mathrm{MeOH}$. After several chromatographic procedures compound $\mathbf{1}$ was isolated from the leaves, while compound $\mathbf{2}$ was obtained from the stems. The two compounds, after detailed spectroscopic analysis, were identified as two new ceramides.

Compound $\mathbf{1}$ was isolated as a white amorphous solid. Its IR spectrum revealed the absorption bands for either secondary amides or hydroxyl groups at $3302 \mathrm{~cm}^{-1}$, an amide carbonyl at $1638 \mathrm{~cm}^{-1}$ and skeletal absorptions at 1547,1518 and $1464 \mathrm{~cm}^{-1}$ for aromatic rings. The molecular formula of $\mathbf{1}, \mathrm{C}_{36} \mathrm{H}_{65} \mathrm{NO}_{2}$, was determined on the basis of high-resolution ESI mass spectrometry in 

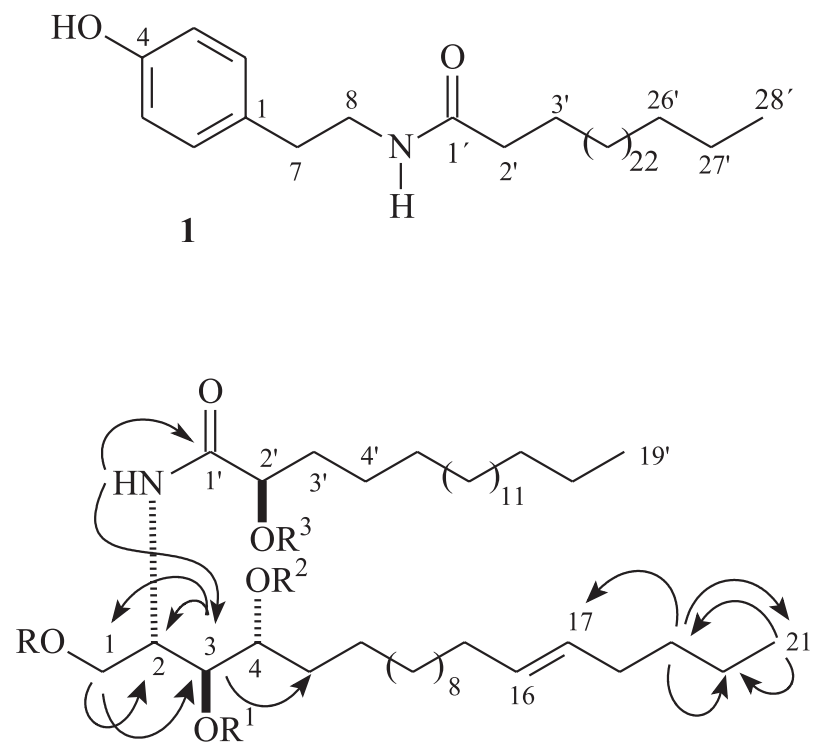

$$
\begin{aligned}
& 2 \mathrm{R}=\mathrm{R}^{1}=\mathrm{R}^{2}=\mathrm{R}^{3}=\mathrm{H} \\
& \text { 2a } \mathrm{R}=\mathrm{R}^{1}=\mathrm{R}^{2}=\mathrm{R}^{3}=\mathrm{Ac}
\end{aligned}
$$

Figure 1. Structures of compounds 1, 2 and the acetylated derivative 2a. Key long-range correlations observed in the HMBC spectrum of $\mathbf{2}$.

the negative mode $\left([\mathrm{M}-\mathrm{H}]^{-}\right)$at $m / z 542.4907\left(\mathrm{C}_{36} \mathrm{H}_{64} \mathrm{NO}_{2}\right.$, calc. 542.4937). The ${ }^{1} \mathrm{H}$ NMR spectrum of 1 exhibited an amide proton at $\delta 8.72(\mathrm{~s})$, two signals, both integrating for two aromatic hydrogens, at $\delta 7.25(\mathrm{~d}, J 8.5 \mathrm{~Hz}$, $\mathrm{H}-2 / \mathrm{H}-6)$ and 7.15 (d, $J 8.5 \mathrm{~Hz}, \mathrm{H}-3 / \mathrm{H}-5)$, a multiplet at $\delta 3.76(2 \mathrm{H}-8)$ characteristic of the methylene attached to the amide nitrogen and a triplet at $\delta 2.97(J 7.5 \mathrm{~Hz}$, $2 \mathrm{H}-7$ ) for the benzyl methylene. As expected, the COSY spectrum showed vicinal scalar coupling for the former methylene with the benzyl methylene and the amide hydrogen. Additionally, the ${ }^{1} \mathrm{H}$ NMR spectrum showed a signal at $\delta 2.41(\mathrm{t}, J 7.5 \mathrm{~Hz}, 2 \mathrm{H}-2$ ') typical of methylene group $\alpha$ to a carbonyl, as well as signals for a terminal methyl group at 0.89 (t, $\left.J 6.5 \mathrm{~Hz}, 3 \mathrm{H}-28^{\prime}\right)$ and a series of aliphatic methylene hydrogens $(\delta 1.39-1.26)$. The ${ }^{13} \mathrm{C}$ NMR spectra of $\mathbf{1}$ showed the presence of a carbonyl signal at $\delta 174.3$ (C-1') for an amide, signals at $\delta 158.7$ (C-4), 131.8 (C-1), 131.7 (C-2/C-6) and 117.6 (C-3/C-5) that justify a para-substituted phenol moiety and two signals at $\delta 43.0(\mathrm{C}-8)$ and $36.9(\mathrm{C}-7)$ for the nitrogenated and benzyl methylene carbons, respectively. The ${ }^{13} \mathrm{C}$ NMR spectrum also revealed a series of signals at $\delta 33.4-24.2$ for the methylene carbons, in addition to a signal at $\delta 15.5$ for a terminal methyl group, suggesting that compound 1 possessed a long alkyl chain. The observed HMBC correlations for the methylene protons at $\delta 3.76(2 \mathrm{H}-8)$ with the carbons at $\delta 174.3\left(\mathrm{C}^{\prime} 1^{\prime}\right)$ and $131.8(\mathrm{C}-1)$ allowed to determine a $N$-(4-hydroxyphenethyl)amide moiety, also justified by the fragment ion peaks at $m / z, 179$
( $\left[p-\mathrm{HO}-\mathrm{C}_{6} \mathrm{H}_{4}-\mathrm{CH}_{2} \mathrm{CH}_{2} \mathrm{NHCOCH}_{3}\right]^{\bullet \bullet}$, deriving from a McLafferty rearrangement), 120 ( $\left[p-\mathrm{HO}-\mathrm{C}_{6} \mathrm{H}_{4}-\mathrm{CH}=\mathrm{CH}_{2}\right]^{+\bullet}$ ) and $107\left(\left[p-\mathrm{HO}-\mathrm{C}_{6} \mathrm{H}_{4}-\mathrm{CH}_{2}\right]^{+}\right)$, in the EI-MS spectrum. Accordingly with the afore mentioned spectral data, the structure of $\mathbf{1}$ was characterized as the $N$-(4-hydroxyphenethyl) octacosamide, an unknown ceramide up to date.

Compound $\mathbf{2}$ was also isolated as a white amorphous solid. Its IR spectrum revealed several broad peaks in the range of $3399-3227 \mathrm{~cm}^{-1}$ characteristic of bonded $\mathrm{N}-\mathrm{H}$ or O-H stretching, the amide carbonyl at $1621 \mathrm{~cm}^{-1}$, followed by the N-H bending at $1544 \mathrm{~cm}^{-1}$. A shoulder at higher frequency than the carbonyl absorption followed by the band at $964 \mathrm{~cm}^{-1}$ is in accordance with a trans carbon-carbon double bond. The long aliphatic chain was characterized by a band at $723 \mathrm{~cm}^{-1}$. The molecular formula of $2, \mathrm{C}_{40} \mathrm{H}_{79} \mathrm{NO}_{5}$, was determined on the basis of highresolution ESI mass spectroscopy in the negative mode $\left([\mathrm{M}-\mathrm{H}]^{-}\right)$at $\mathrm{m} / z 652.5983\left(\mathrm{C}_{40} \mathrm{H}_{78} \mathrm{NO}_{5}\right.$, calc. 652.5880). The ${ }^{1} \mathrm{H}$ NMR spectrum showed characteristic signal for an amide proton at $\delta 8.60(\mathrm{~d}, J 8.9 \mathrm{~Hz})$, resonances for four hydroxyl groups at $\delta$ 7.63, 6.72 (integrating for two hydrogens) and 6.10, all appearing as broad singlet; a signal at $\delta 5.15(\mathrm{~m}, \mathrm{H}-2)$ for a methine bonded to a nitrogen; signals at $\delta 4.54(\mathrm{dd}, J 10.9$ and $4.5 \mathrm{~Hz}, \mathrm{H}-1 \mathrm{a})$ and 4.44 (dd, $J 10.9$ and $4.8 \mathrm{~Hz}, \mathrm{H}-1 \mathrm{~b}$ ) for a hydroxymethylene, as well as signals at $\delta 4.64\left(\mathrm{H}-2^{\prime}\right), 4.38(\mathrm{~m}, \mathrm{H}-3)$ and 4.32 (m, H-4) corresponding to three oxymethines. Additionally, signals for a double bond at $\delta 5.59(\mathrm{td}, J 15.4$ and $5.4 \mathrm{~Hz}$, $\mathrm{H}-16)$ and 5.50 (td, $J 15.4$ and $5.8 \mathrm{~Hz}, \mathrm{H}-17$ ), two terminal methyl at $\delta 0.88$ (t, $\left.J 6.2 \mathrm{~Hz}, 3 \mathrm{H}-19^{\prime} / 3 \mathrm{H}-21\right)$ and several methylene hydrogens at $\delta 2.29-1.28$ corresponding to two aliphatic chains were also observed. The COSY spectrum revealed coupling for the methine attached to the nitrogen $(\mathrm{H}-2)$ with the oxymethylene $(2 \mathrm{H}-1)$ and an oxymethine $(\mathrm{H}-3)$ protons, and the latter with the oxymethine $\mathrm{H}-4$. As expected, the ${ }^{13} \mathrm{C}$ NMR spectra of 2 exhibited three downfield carbon signals at $\delta 175.7$ (C-1'), 131.3 (C-16) and $131.2(\mathrm{C}-17)$ corresponding to a carbonyl amide and a double bond, respectively. Signals for a nitrogenated methine at $\delta 54.4(\mathrm{C}-2)$, an oxymethylene at $\delta 62.5(\mathrm{C}-1)$ and three oxymethynes at $\delta 77.2(\mathrm{C}-3), 73.5(\mathrm{C}-4)$ and 72.9 (C-2'). In addition, several carbon signals in the range of $\delta$ 36.2-23.4 related to methylene groups and a carbon signal at 14.8 corresponding to two terminal methyls were also deduced from ${ }^{13} \mathrm{C}$ NMR spectra, suggesting that compound 2 was also a ceramide. The unequivocal positions of the hydroxyl groups were deduced based on the HMBC spectrum in which the proton signal at $\delta 8.60(\mathrm{NH})$ showed correlations with the carbonyl (C-1') and the nitrogenated methine $(\mathrm{C}-2)$, while the proton signal at $\delta 5.15(\mathrm{H}-2)$ exhibited correlations with the carbon signals at $\delta 62.5$ 
(C-1), 77.2 (C-3) and 73.5 (C-4). Furthermore, HMBC correlation between the proton signal at $4.64\left(\mathrm{H}-2^{\prime}\right)$ and the carbonyl (C-1') confirmed the presence of a side chain of a $\alpha$-hydroxy fatty acid. Subsequently, the four hydroxyl groups were confirmed through the acetylated compound (2a). The HMQC spectrum showed the obvious additional methyl signals at $\delta_{\mathrm{H}} / \delta_{\mathrm{C}} 2.23 / 21.2,2.13 / 21.1,2.10 / 21.5$ and $2.08 / 21.3$ characteristic of the four acetyl moieties. Through the HMBC spectra of both compounds $\mathbf{2}$ and $\mathbf{2 a}$ the double bond was assigned at $\mathrm{C}-16$ and $\mathrm{C}-17$ of the sphingoid chain. HMBC correlations found for $3 \mathrm{H}-21(\delta 0.88)$ and $\mathrm{H}-17$ $(\delta 5.50)$ with $\mathrm{C}-19(\delta$ 32.6) supported this deduction. The $E$-configuration established for C-16/C-17 double bond was determined through the large vicinal coupling constant $(J 15.4 \mathrm{~Hz}$ ) displayed between $\mathrm{H}-16$ and $\mathrm{H}-17$. The low resolution mass spectrum of $\mathbf{2}$ was crucial to the definition of the amide and of the sphingoid portions length. The peaks at $\mathrm{m} / \mathrm{z} 384,357$ and 339 were in agreement with the sphingoid moiety when combined with the peaks at $\mathrm{m} / z 298$ and 280, represented by the structural fragments sketched in Figure S10 (Supplementary Information), were congruent with the proposed structure. After comparison with analogous compounds ${ }^{16-18}$ the relative stereochemistry inferred for the stereocenters 2, 3, 4 and 2' was presumed to be $S^{*}, S^{*}, R^{*}$ and $R^{*}$, respectively. On the basis of the above mentioned data, the structure of compound $\mathbf{2}$ was established as rel$(2 S, 3 S, 4 R, 16 E)-2$-[(2'R)-2'-hydroxynonadecanoylamino]heneicosadec-16-ene-1,3,4-triol.

\section{Experimental}

\section{General experimental procedures}

Melting points were measured on a digital Mettler Toledo FP90 apparatus and are uncorrected. The optical rotations were measured on a Perkin-Elmer 341 digital polarimeter. IR spectra were recorded using a Perkin-Elmer FT-IR 1000 spectrometer. Electrospray ionization-High resolution mass spectra were measured on a quadrupole-time of flight instrument (UltrOTOF-Q, Bruker Daltonics, Billerica, $\mathrm{MA}$ ), while the low resolution Electron ionization mass spectra were acquired on a Shimadzu QP5050A instrument, through direct probe and operating at $70 \mathrm{eV}$. All NMR experiments were performed on a Bruker Avance DRX-500 spectrometer equipped with a $5 \mathrm{~mm}$ inverse detection z-gradient probe. ${ }^{1} \mathrm{H}$ NMR $(500.13 \mathrm{MHz})$ and ${ }^{13} \mathrm{C}$ NMR $(125.77 \mathrm{MHz})$ spectra were measured at $27{ }^{\circ} \mathrm{C}$ using pyridine- $d_{5}$ as solvent. Chemical shifts, given on the $\delta$ scale, were referenced to the residual pyridine $\left[\delta_{\mathrm{H}} 8.74,7.58,7.22\right.$; $\left.\delta_{\mathrm{C}} 150.35,135.91,123.87\right]$. Column chromatography was run using silica gel 60 (70-230 mesh, Vetec; 230-400 mesh,
Merck) and TLC was performed on precoated silica gel polyester sheets (Kieselgel $60 \mathrm{~F}_{254}, 0.20 \mathrm{~mm}$, Merck) by detection with a spray reagent of vanillin/perchloric acid/ EtOH solution followed by heating at $100{ }^{\circ} \mathrm{C}$.

\section{Plant material}

Acnistus arborescens was harvested in August 2006, in the Pico Alto locality (Guaramiranga Mountain, State of Ceará), at an elevation of $1000 \mathrm{~m}$. The plant material was identified by Professor Edson P. Nunes. A voucher specimen (No. 30.513) is deposited in the Herbário Prisco Bezera (EAC) of the Departamento de Biologia, Universidade Federal do Ceará.

\section{Extraction and isolation}

The leaves $(3.7 \mathrm{~kg})$ and stems $(3.0 \mathrm{~kg})$ of A. arborescens were separately soaked with $\mathrm{EtOH}(2 x)$ at room temperature for $72 \mathrm{~h}$. The extracts were concentrated under vacuum and the residues (leaves $=170 \mathrm{~g}$; stems $=57 \mathrm{~g}$ ) fractioned over silica gel using $n$-hexane, $\mathrm{CH}_{2} \mathrm{Cl}_{2}$, EtOAc and $\mathrm{MeOH}$ as eluents. The $\mathrm{CH}_{2} \mathrm{Cl}_{2}$ fraction (45 g), obtained from the leaf EtOH extract, was subjected to gravity column chromatography over silica gel by elution with $n$-hexane and $n$-hexane:EtOAc in increasing order of polarity. The $n$-hexane:EtOAc fraction 6:4 (24.1 g) after repeated column chromatography yielded compound $\mathbf{1}(30 \mathrm{mg})$ by elution with $\mathrm{CH}_{2} \mathrm{Cl}_{2}$ :EtOAc (8:2). The EtOAc fraction (15.5 g), originated from the stem EtOH extract, was subjected to Si-gel column chromatography using gradients of increasing amounts of EtOAc (20-100\%) in $n$-hexane, followed by EtOAc:MeOH (9:1) to afford 8 fractions (A-H) on the basis of TLC profile. Fraction G (46 mg) was subjected to silica gel flash chromatography using EtOAc: $\mathrm{MeOH}$ (9.5:0.5) to afford compound 2 (18 mg).

$N$-(4-hydroxyphenethyl)octacosamide (1): White amorphous solid; mp 116.0-119.4 ${ }^{\circ} \mathrm{C}$; IR $(\mathrm{KBr}) \mathrm{v}_{\max } / \mathrm{cm}^{-1}$ 3302, 3081, 2919, 2850, 1638, 1547, 1518, 1464, 1250, 1111; HRESIMS m/z 542.4907 [M-H] -; EIMS m/z 543 ([M] $]^{+}$, absent), 179 (2), 121 (72), 120 (100), 107 (35); ${ }^{1} \mathrm{H}$ $(500.13 \mathrm{MHz})$ and ${ }^{13} \mathrm{C}$ NMR (125.77 MHz) data, see Table 1.

rel-(2S, 3S, 4R, 16E)-2-[(2'R)-2'-hydroxynonadecanoylamino]-heneicosadec-16-ene-1,3,4-triol. (2): White amorphous solid; $m p$ 109.4-111. ${ }^{\circ} \mathrm{C} ;[\alpha]_{\mathrm{D}}^{20}+9^{\circ}$ (c 0.2, pyridine); IR (KBr) $v_{\text {max }} / \mathrm{cm}^{-1} 3399-3227,2919,2850$, 1621, 1544, 1467, 1069, 964, 723; HRESIMS m/z 652.5983 [M-H] ${ }^{-}$; EIMS m/z 653 ([M]+, absent), 408 (9), 384 (15), 370 (9), 357 (36), 339 (26), 308 (10), 298 (10), 280 (24), 
Table 1. ${ }^{1} \mathrm{H}$ and ${ }^{13} \mathrm{C}$ NMR spectral data for compounds $\mathbf{1}$ and $\mathbf{2}$, in pyridine- $d_{5}$

\begin{tabular}{|c|c|c|c|c|c|}
\hline \multicolumn{3}{|c|}{1} & \multicolumn{3}{|c|}{2} \\
\hline No. & $\delta_{C} / \mathrm{ppm}$ & $\delta_{\mathrm{H}} / \mathrm{ppm}$ & No. & $\delta_{C} / \mathrm{ppm}$ & $\delta_{\mathrm{H}} / \mathrm{ppm}$ \\
\hline 1 & 131.8 & - & 1 & 62.5 & $\begin{array}{l}4.54(\mathrm{dd}, J 10.9 ; 4.5) \\
4.44(\mathrm{dd}, J 10.9 ; 4.8)\end{array}$ \\
\hline 2 & 131.7 & $7.25(\mathrm{~d}, J 8.5)$ & 2 & 53.4 & $5.15(\mathrm{~m})$ \\
\hline 3 & 117.6 & $7.15(\mathrm{~d}, J 8.5)$ & 3 & 77.2 & $4.38(\mathrm{~m})$ \\
\hline 4 & 158.7 & - & 4 & 73.5 & $4.32(\mathrm{~m})$ \\
\hline 5 & 117.6 & $7.15(\mathrm{~d}, J 8.5)$ & 5 & 34.6 & $2.29(\mathrm{~m}) ; 1.95(\mathrm{~m})$ \\
\hline 6 & 131.7 & $7.25(\mathrm{~d}, J 8.5)$ & 6 & 26.3 & $1.74(\mathrm{~m}) ; 1.77(\mathrm{~m})$ \\
\hline 7 & 36.9 & $2.97(\mathrm{t}, J 7.5)$ & $7-14$ & $30.8-30.0$ & $1.33-1.28$ \\
\hline 8 & 43.0 & $3.76(\mathrm{~m})$ & 15 & $33.5^{\mathrm{a}}$ & $2.02(\mathrm{~m})$ \\
\hline $1^{\prime}$ & 174.3 & - & 16 & $131.3^{\mathrm{b}}$ & $5.59(\mathrm{td}, J 15.4 ; 5.4)$ \\
\hline $2^{\prime}$ & 38.0 & $2.41(\mathrm{t}, J 7.5)$ & 17 & $131.2^{\mathrm{b}}$ & $5.50(\mathrm{td}, J 15.4 ; 5.8)$ \\
\hline $3^{\prime}$ & 27.6 & $1.87(\mathrm{~m})$ & 18 & $33.8^{\mathrm{a}}$ & $2.02(\mathrm{~m})$ \\
\hline $4^{\prime}-25^{\prime}$ & $31.3-31.0$ & $1.39-1.26$ & 19 & 32.6 & $1.33-1.28$ \\
\hline $26^{\prime}$ & 33.4 & $1.39-1.26$ & 20 & 23.4 & $1.33-1.28$ \\
\hline $27^{\prime}$ & 24.2 & $1.39-1.26$ & 21 & 14.8 & $0.88(\mathrm{t}, J 6.2)$ \\
\hline $28^{\prime}$ & 15.5 & $0.89(\mathrm{t}, J 6.5)$ & 1 ' & 175.7 & - \\
\hline \multirow[t]{12}{*}{$\mathrm{N}-\mathrm{H}$} & - & $8.72(\mathrm{~s})$ & 2 ' & 72.9 & $4.64(\mathrm{~m})$ \\
\hline & & & 3 ' & 36.2 & $2,19(\mathrm{~m}) ; 2.06(\mathrm{~m})$ \\
\hline & & & $4^{\prime}$ & 27.1 & $1.33-1.28$ \\
\hline & & & $5^{\prime}-16^{\prime}$ & $30.8-30.0$ & $1.33-1.28$ \\
\hline & & & $17^{\prime}$ & 32.6 & $1.33-1.28(\mathrm{~m})$ \\
\hline & & & $18^{\prime}$ & 23.4 & $1.33-1.28(\mathrm{~m})$ \\
\hline & & & $19^{\prime}$ & 14.8 & $0.88(\mathrm{t}, J 6.2)$ \\
\hline & & & $\mathrm{N}-\mathrm{H}$ & - & $8.60(\mathrm{~d}, J 8.9)$ \\
\hline & & & HO-1 & - & $6.72(\mathrm{br} \mathrm{s})$ \\
\hline & & & HO-3 & - & 6.72 (br s) \\
\hline & & & $\mathrm{HO}-4$ & - & 6.10 (br s) \\
\hline & & & HO-2' & - & 7.63 (br s) \\
\hline
\end{tabular}

${ }^{\mathrm{a}, \mathrm{b}}$ Signals can be interchangeable.

279 (7), 265 (12), 97 (29), 83 (35), 57 (47), 43 (100); ${ }^{1} \mathrm{H}\left(500.13 \mathrm{MHz}\right.$, pyridine- $\left.d_{5}\right)$ and ${ }^{13} \mathrm{C}$ NMR $(125.77 \mathrm{MHz}$, pyridine- $d_{5}$ ) data, see Table 1 .

Acetylation of 2: Compound 2 (12 mg) was dissolved in a mixture of pyridine/acetic anhydride 1:2 $(1 \mathrm{~mL})$, under catalytic amounts of DMAP, and stirred for $3 \mathrm{~h}$ at room temperature. After this, the reaction mixture was neutralized with a solution of $\mathrm{HCl} 1 \mathrm{~mol} \mathrm{~L}^{-1}$ (4 drops) and extracted with $\mathrm{CH}_{2} \mathrm{Cl}_{2}(3 \times 10 \mathrm{~mL})$. The $\mathrm{CH}_{2} \mathrm{Cl}_{2}$ layer was evaporated under reduced pressure to yield the peracetylated 2a (12 mg). White amorphous solid; $\mathrm{mp} 52.8-54.6{ }^{\circ} \mathrm{C} ;{ }^{1} \mathrm{H}$ NMR $\left(500.13 \mathrm{MHz}, \mathrm{CDCl}_{3}\right): \delta 6.64(1 \mathrm{H}, \mathrm{d}, J 8.9 \mathrm{~Hz}, \mathrm{NH}), 5.48-$ $5.37(2 \mathrm{H}, \mathrm{m}, \mathrm{H}-16$ and $\mathrm{H}-17), 5.15\left(1 \mathrm{H}, \mathrm{m}, \mathrm{H}-2^{2}\right), 5.14$ $(1 \mathrm{H}, \mathrm{m}, \mathrm{H}-3), 5.0(1 \mathrm{H}, \mathrm{br}, \mathrm{d}, J 9.4 \mathrm{~Hz}, \mathrm{H}-4), 4.49(1 \mathrm{H}, \mathrm{br}$, s, H-2), 4.39 (1H, dd, J 11.7, $6.5 \mathrm{~Hz}, \mathrm{H}-1 \mathrm{a}), 4.06$ (1H, dd, $J 11.7,2.8 \mathrm{~Hz}, \mathrm{H}-1 \mathrm{~b}$ ), 2.06-1.90 (4H, m, $2 \mathrm{H}-15$ and $2 \mathrm{H}-18$ ), $1.85(4 \mathrm{H}, \mathrm{m}, 2 \mathrm{H}-3$ ' and 2H-4'), 1.80-1.60 (2H, m, 2H-5), $1.50-1.20(56 \mathrm{H}, \mathrm{m}, 2 \mathrm{H}-6-2 \mathrm{H}-14,2 \mathrm{H}-19,2 \mathrm{H}-20$ and $2 \mathrm{H}-5$ '$\left.2 \mathrm{H}-21^{\prime}\right), 0.93$ (6H, t, $J 6.6 \mathrm{~Hz}, 3 \mathrm{H}-21$ and $3 \mathrm{H}-22$ ') 2.23 , 2.13, 2.10, 2.08 (s each, $4 \times \mathrm{AcO}) .{ }^{13} \mathrm{C}$ NMR $(125.77 \mathrm{MHz}$, $\left.\mathrm{CDCl}_{3}\right) \delta 171.0$ (C-1'), 131.6 (C-16), 129.9 (C-17), 74.5 (C-2'), 73.2/73.0 (C-4), 72.7 (C-3), 62.8 (C-1), 48.3 (C-2), 33.0 (C-15), 32.6 (C-18), 32.4 (C-3'), 32.2 (C-19 and C-20'), 30.1-28.6 (C-5, C-7 - C-14, C-5'-C-19'), 25.3 (C-6 and C-4'), 23.1 (C-20 and C-21'), 14.5 (C-21 and C-22'), 171.6/21.5, 171.6/21.3, 170.5/21.2, 170.5/21.1 (4× AcO). EIMS $m / z 864$ ([M] $]^{+}$, absent), 790 (93), 776 (60), 761 (41), 748 (100), 733 (41), 705 (12), 691 (29), 583 (29), 483 (10), 440 (47), 310 (15), 261 (23), 139 (17), 56 (35). 


\section{Supplementary Information}

Supplementary information for compounds $\mathbf{1}$ and $\mathbf{2}$ is available free of charge as PDF file at http://jbcs.sbq.org.br

\section{Acknowledgments}

The authors thanks to Prof. Edson P. Nunes for the plant identification and João Carlos Assunção for the LR mass spectra. This work was supported by grants from the Brazilian Governmental Agencies: CAPES, CNPq, PRONEX and FUNCAP.

\section{References}

1. Hawkes, J. G.; Lester, R. N.; Nee, M.; Estrada, N.; Solanaceae III: Taxonomy, Chemistry, Evolution. Royal Botanic Gardens, Kew: Great Britain, 1991.

2. Usubillaga, A.; Castellano G.; Zabel, V.; Watson, W. H.; J. Chem. Soc., Chem. Commun. 1980, 854.

3. Nittala, S. S.; Lavie, D.; Phytochemistry 1981, 20, 2735.

4. Burton, G.; Veleiro, A. S.; Gros E. G.; J. Chromatogr., B 1984, $315,435$.

5. Veras, M. L.; Bezerra, M. Z. B.; Lemos, T. L. G.; Uchoa, D. E. A.; Braz-Filho, R.; Chai, H. B.; Cordell, G. A.; Pessoa, O. D. L.; J. Nat. Prod. 2004, 67, 710 .

6. Veras, M. L.; Bezerra, M. Z. B.; Braz-Filho, R.; Pessoa, O. D. L.; Montenegro, R. C.; Pessoa, Ó. C.; Moraes, M. O.; CostaLotufo, L. V.; Planta Med. 2004, 70, 551.

7. Kupchan, S. M.; Anderson, W. K.; Bollinger, P.; Doskotch, R. W.; Smith, R. M.; Renauld, J. A. S.; Schnoes, H. K.; Burlingame, A. L.; Smith, D. H.; J. Org. Chem. 1969, 34, 3858.
8. Minguzzi, S.; Barata, L. E. S.; Shin, Y. G.; Jonas, P. F.; Chai, H. B.; Park, E. J.; Pezzuto, J. M.; Cordell, G. A.; Phytochemistry 2002, 59, 635.

9. Su, B. N.; Misico, R.; Park, E. J.; Santarsiero, B. D.; Mesecar, A. D.; Fong, H. H. S.; Pezzuto, J. M.; Kinghorn, A. D.; Tetrahedron 2002, 58, 3453 .

10. Gao, J. M.; Zhang, A. L.; Chen, H.; Liu, J. K.; Chem. Phys. Lipids 2004, 131, 205.

11. Nakao, Y.; Takada, K.; Matsunaga, S.; Fusetani, N.; Tetrahedron 2001, 57, 3013.

12. Parrinello, N.; Cammarata, M.; Lipar, L.; Arizza, V.; Dev. Comp. Immunol. 1995, 19, 31.

13. Jim, W.; Rinehart, K. L.; Jares-Erijman, E. A.; J. Org. Chem. 1994, 59, 144.

14. Garg, H. S.; Sharma, M.; Bhakuni, D. S.; Pramanik, B. N.; Bose, A. K.; Tetrahedron Lett. 1992, 33, 1641.

15. Jeong, T. S.; Ahn, J. A.; Kim, Y. K.; Bok, S. H.; Kwon, B. M.; Shin, J.; Seo, Y.; Bioorg. Med. Chem. Lett. 1997, 7, 1481.

16. Ramos, F.; Takaishi, Y.; Kawazoe, K.; Osório, C.; Duque, C.; Acuña. R.; Fujimoto, Y.; Sato, M.; Okamoto, M.; Oshikawa, T.; Ahmed, S.U.; Phytochemistry 2006, 67, 1143.

17. Sandjo, L. P.; Hannewald, P.; Yemloul, M.; Kirsch, G.; Ngadjui, B. T.; Helv. Chim. Acta. 2008, 91, 1326.

18. Christophe, C. F.; Kouam, S.; Kouam, S. F.; Herve, M. P.; Simo, I. K.; Ngadjui, B. T.; Green, I. R.; Krohn, K.; Biochem. Syst. Ecol. 2008, 36, 238.

Received: February 26, 2009

Web Release Date: February 11, 2010

FAPESP helped in meeting the publication costs of this article. 


\section{New Ceramides from Acnistus arborescens}

Ana Isabel V. Maia, ${ }^{a}$ Maria Leopoldina Veras, ${ }^{a}$ Raimundo Braz-Filho, ${ }^{a}$ Norberto P. Lopes, ${ }^{b}$ Edilberto R. Silveira ${ }^{a}$ and Otilia Deusdênia L. Pessoa*,a

${ }^{a}$ Departamento de Química Orgânica e Inorgânica, Centro de Ciências, Universidade Federal do Ceará, CP 12200, 60021-970 Fortaleza-CE, Brazil

${ }^{b}$ Departamento de Física e Química, Faculdade de Ciências Farmacêuticas de Ribeirão Preto, Universidade de São Paulo, 14040-903 Ribeirão Preto-SP, Brazil

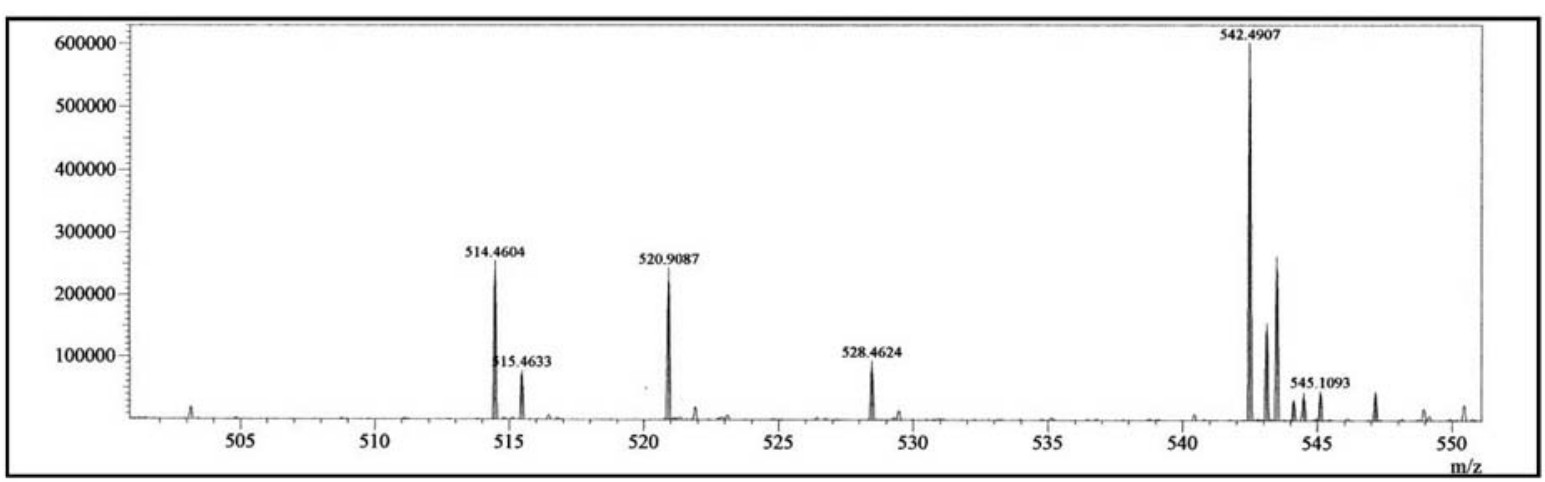

Figure S1. HR-ESI-Mass spectrum of compound $\mathbf{1 .}$

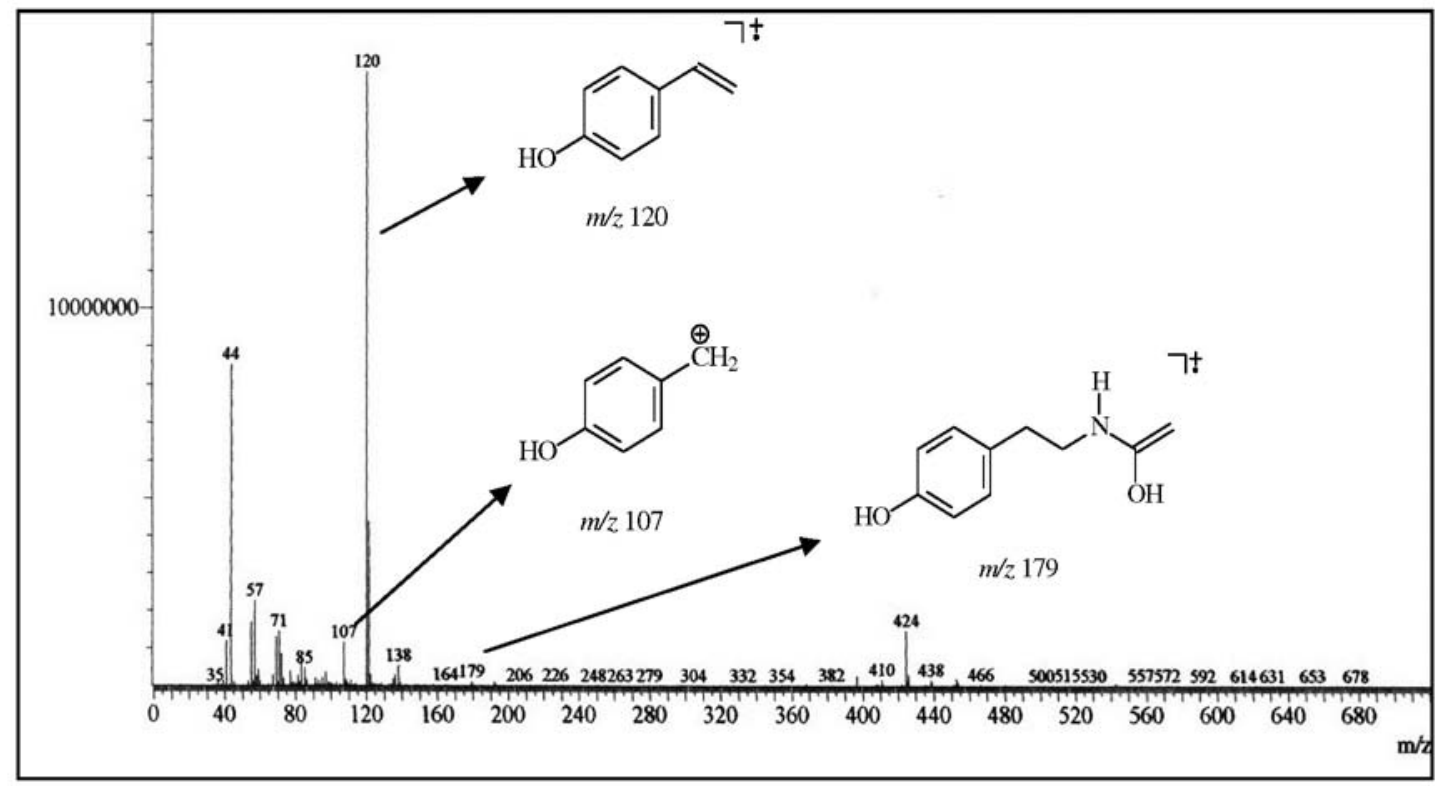

Figure S2. LR-Mass spectrum of compound $\mathbf{1}$. 


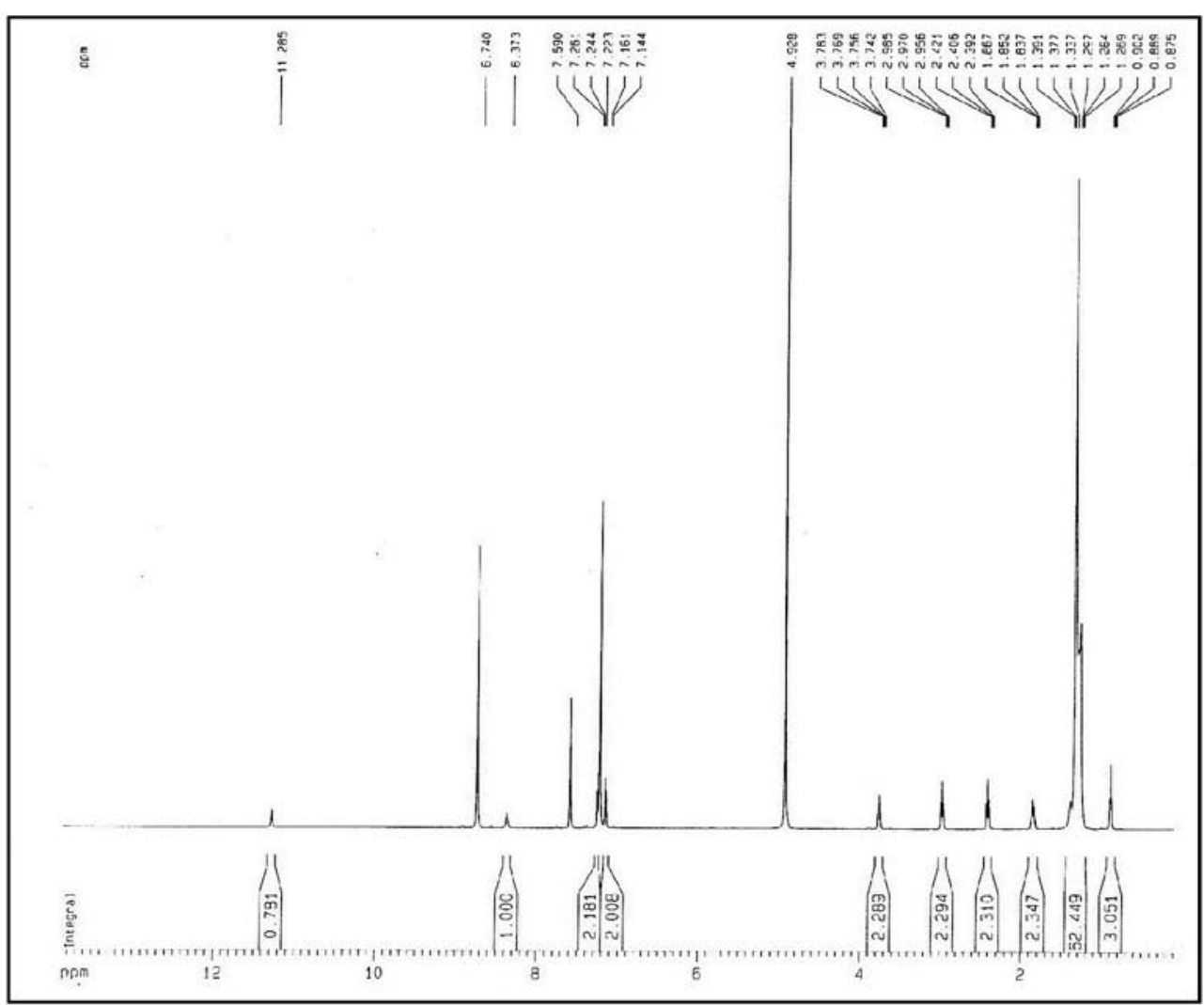

Figure S3. ${ }^{1} \mathrm{H}$ NMR spectrum of compound $\mathbf{1}$ (pyridine- $d_{5}, 500 \mathrm{MHz}$ ).



Figure S4. ${ }^{13} \mathrm{C}$ NMR spectrum of compound $\mathbf{1}$ (pyridine- $d_{5}, 125 \mathrm{MHz}$ ). 


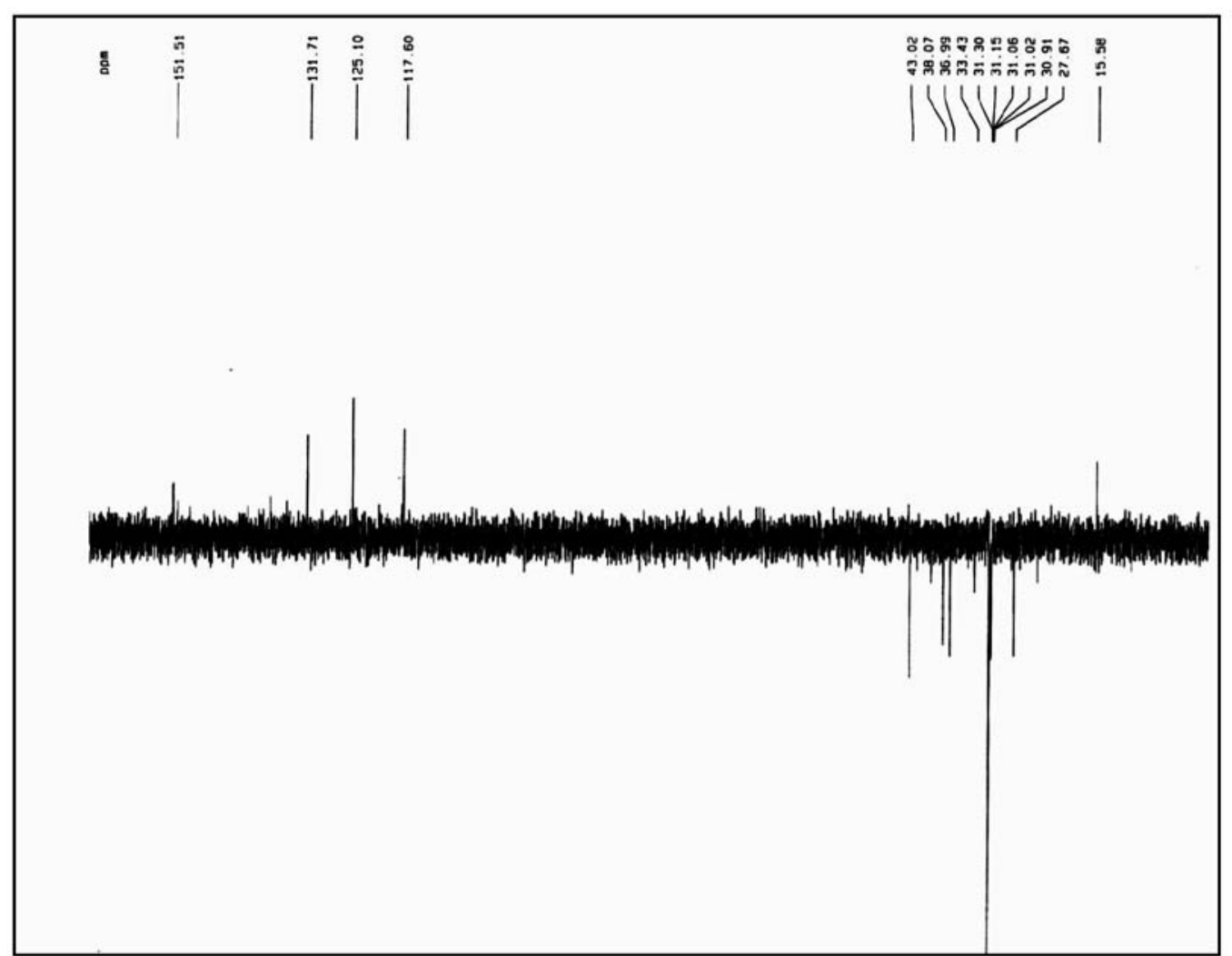

Figure S5. ${ }^{13} \mathrm{C}$ NMR - DEPT spectrum of compound $\mathbf{1}$ (pyridine- $d_{5}, 125 \mathrm{MHz}$ ).

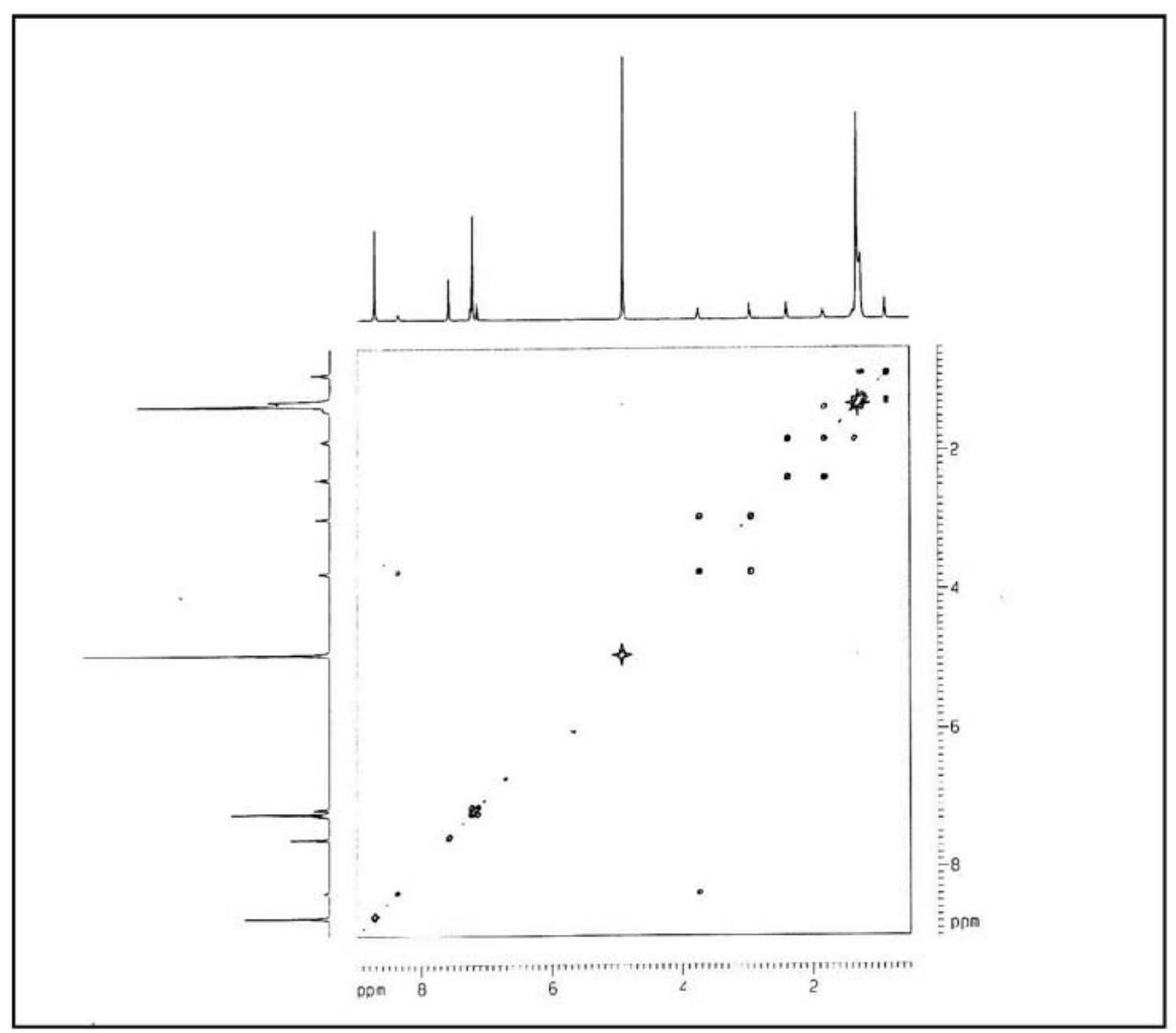

Figure S6. ${ }^{1} \mathrm{H},{ }^{1} \mathrm{H}$ COSY spectrum of compound $\mathbf{1}$ (pyridine- $d_{5}$ ). 


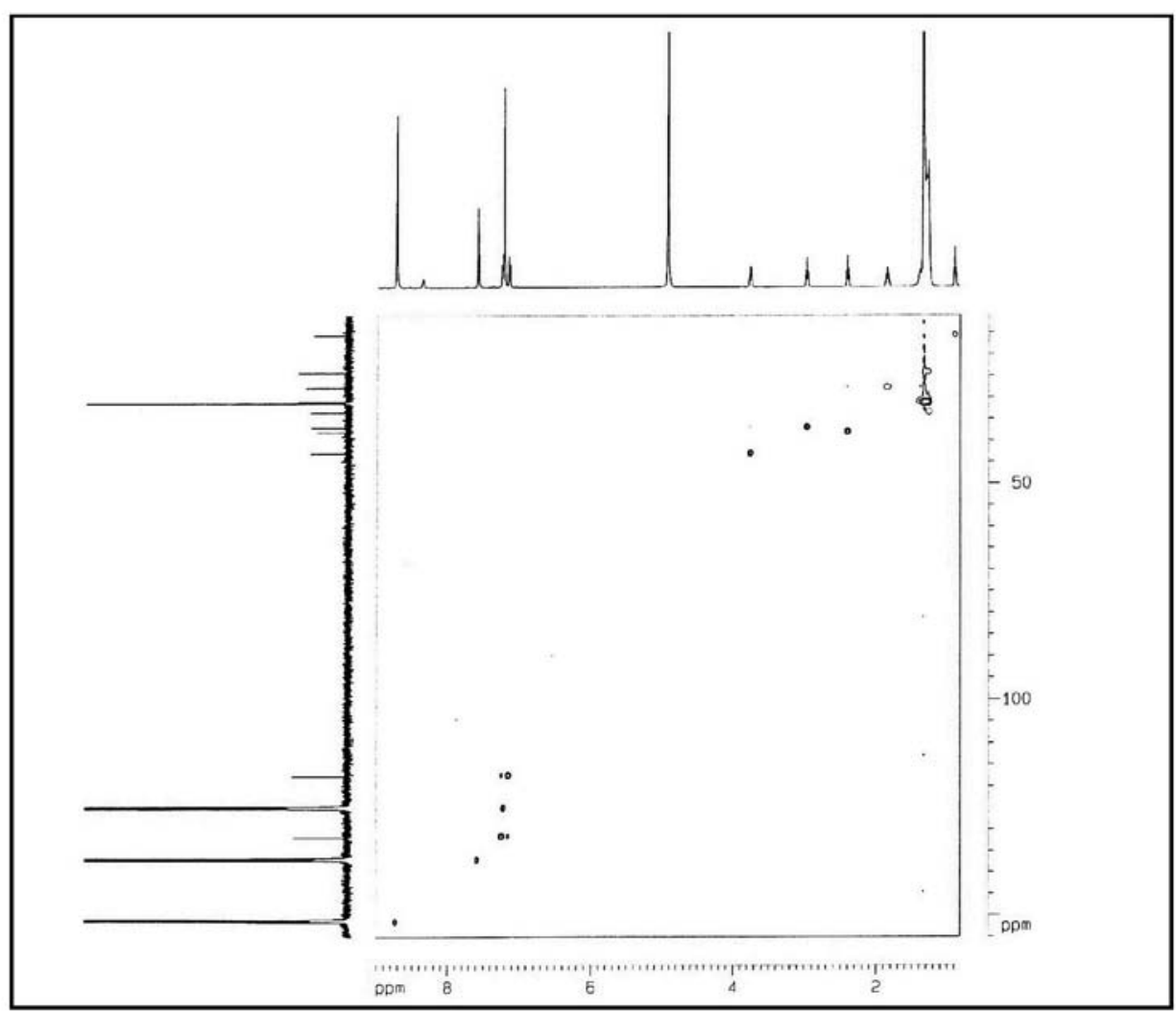

Figure S7. HMQC spectrum of compound 1 (pyridine- $d_{5}$ ).

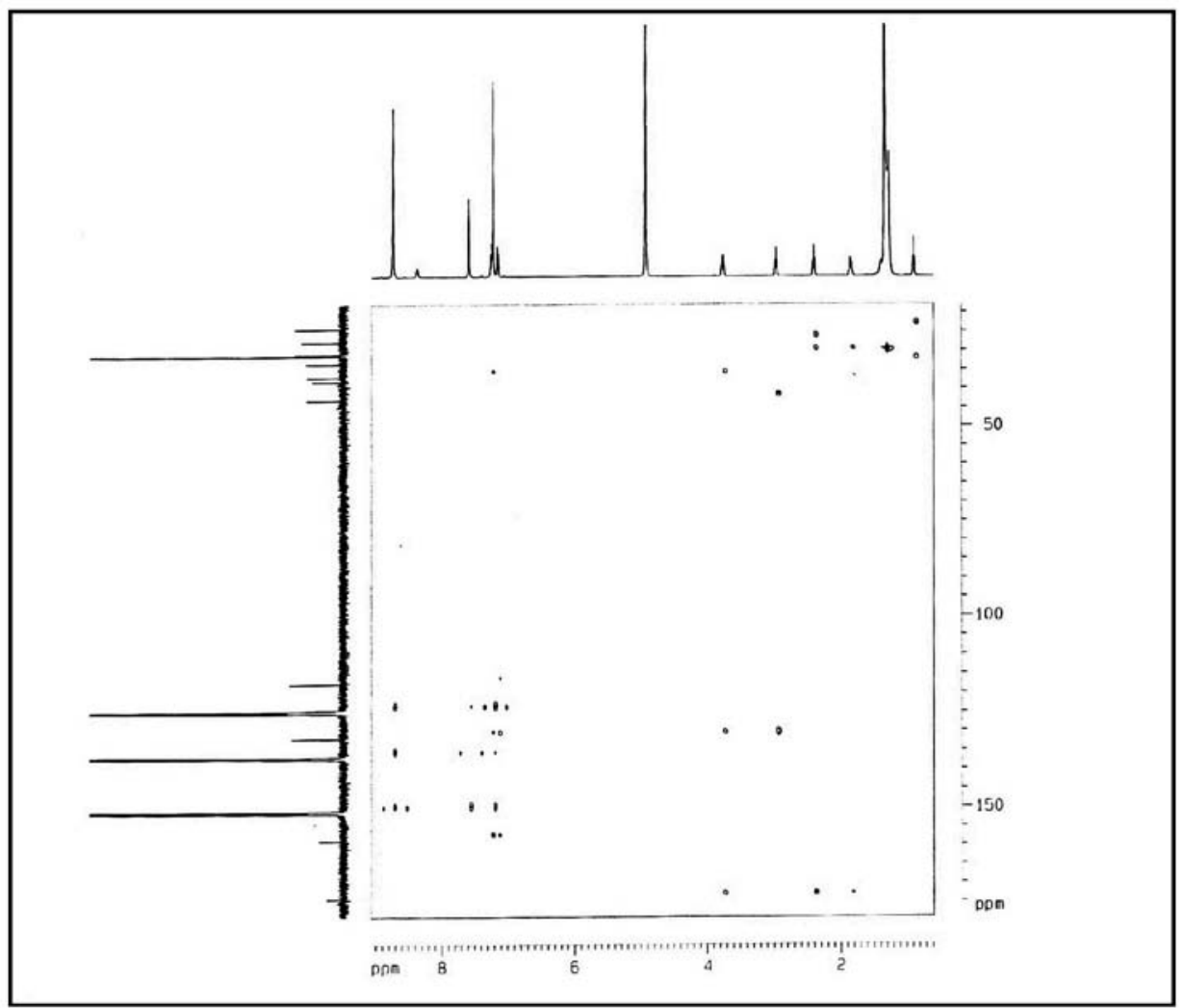

Figure S8. HMBC spectrum of compound 1 (pyridine- $d_{5}$ ). 


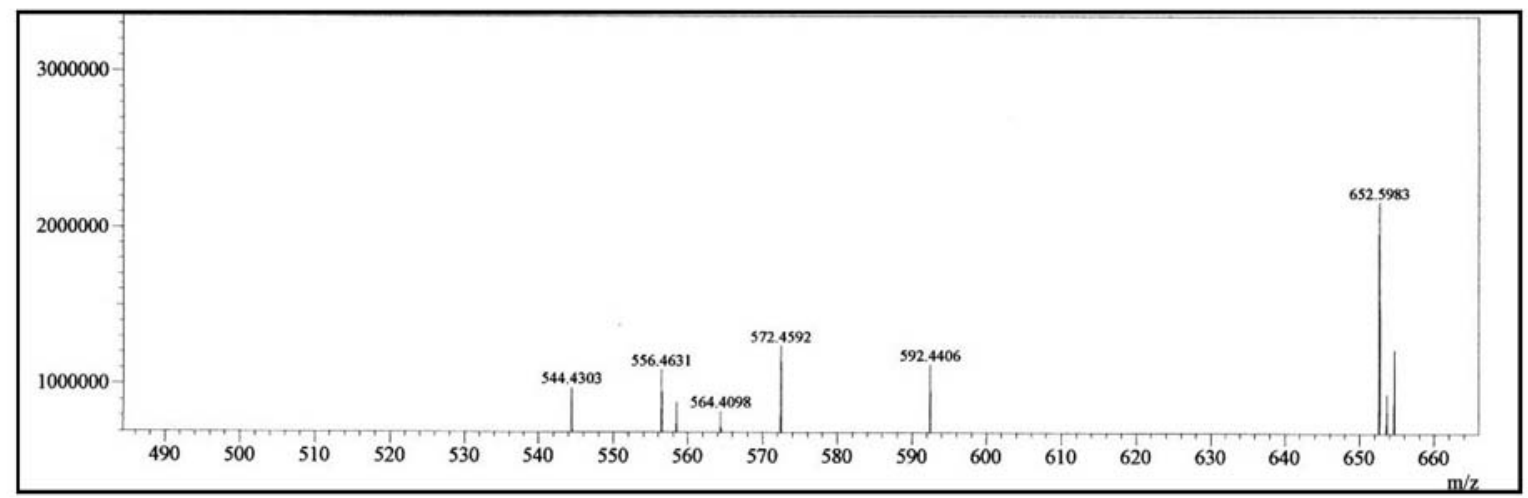

Figure S9. HR-ESI-Mass spectrum of compound 2.

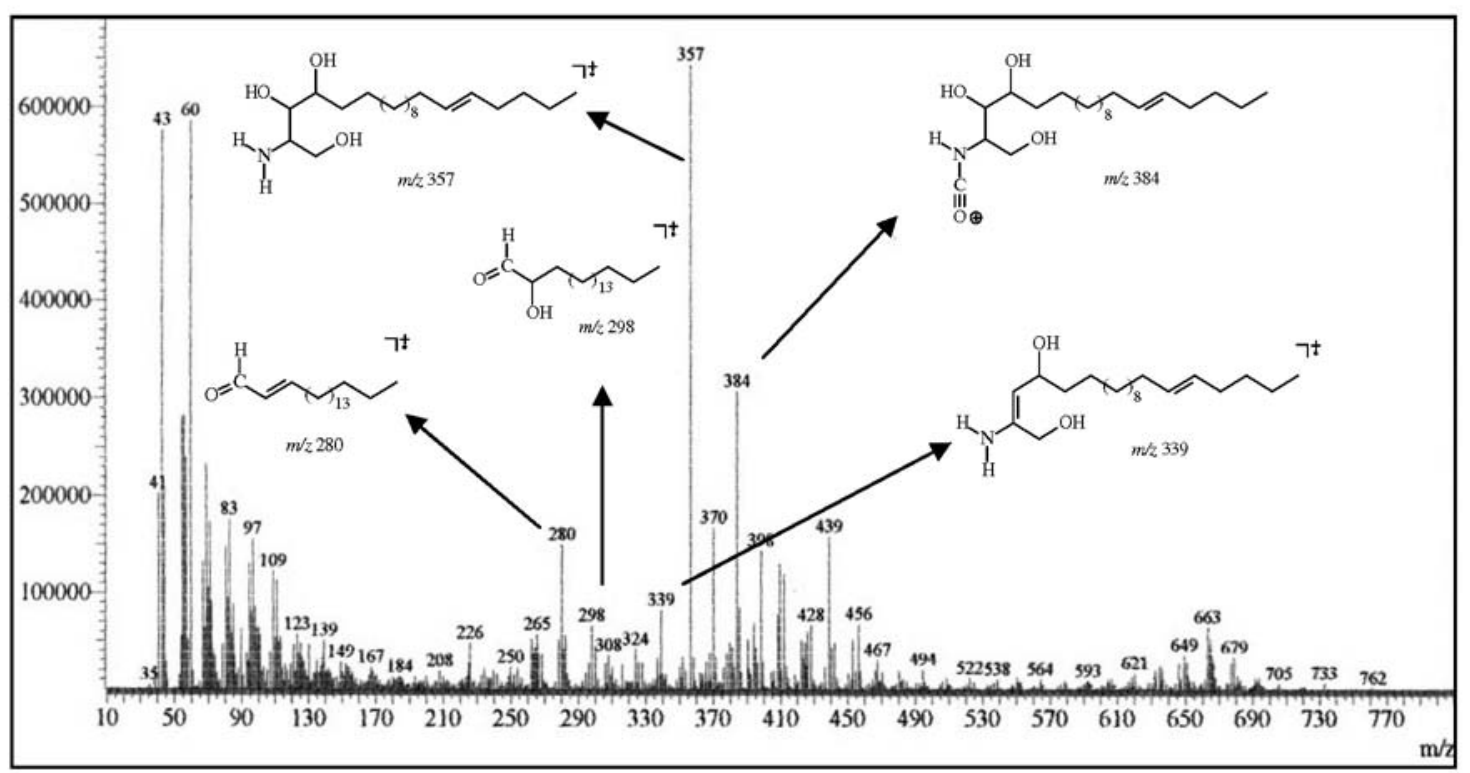

Figure S10. LR-Mass spectrum of compound 2. 


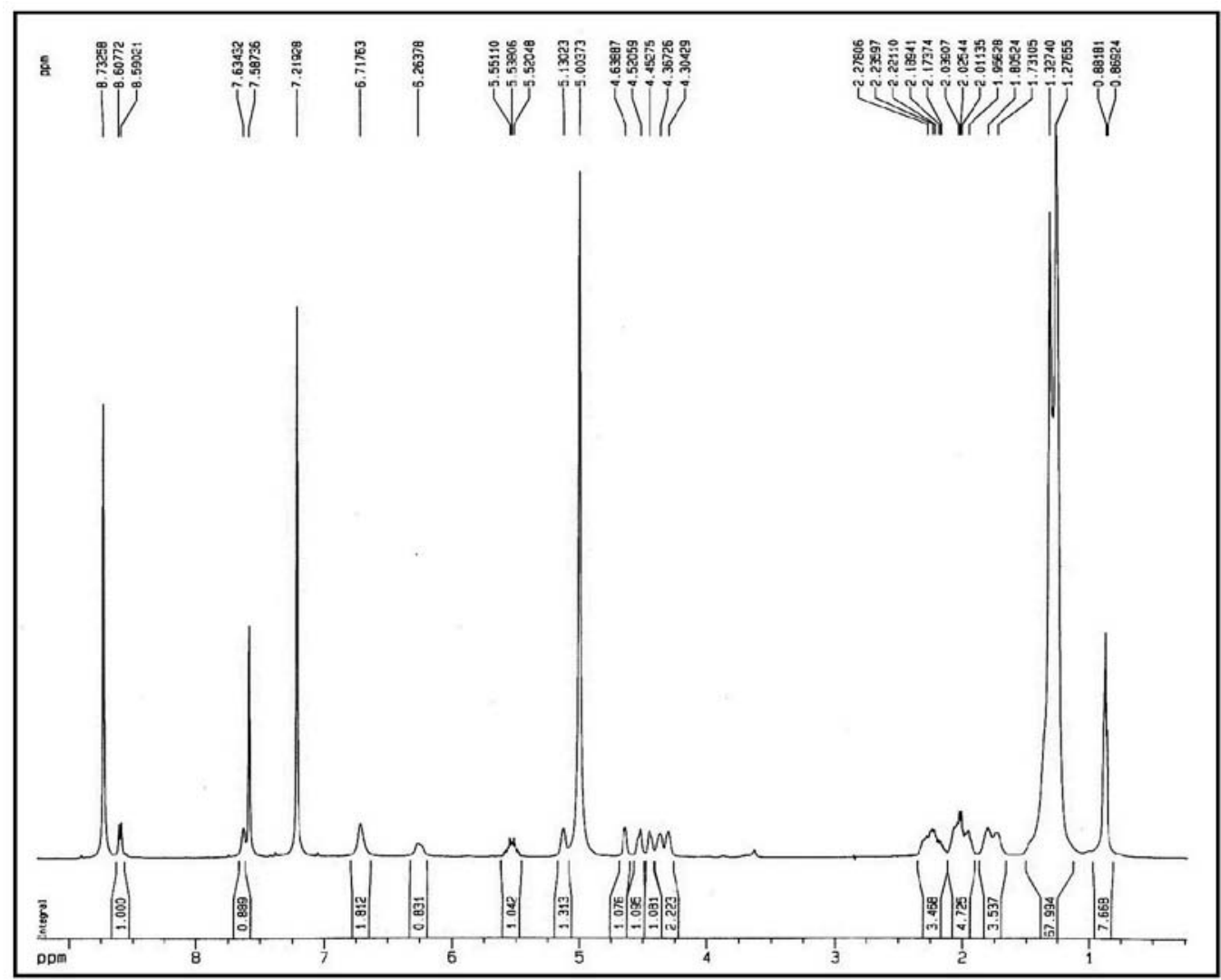

Figure S11. ${ }^{1} \mathrm{H}$ NMR spectrum of compound 2 (pyridine- $d_{5}, 500 \mathrm{MHz}$ ).

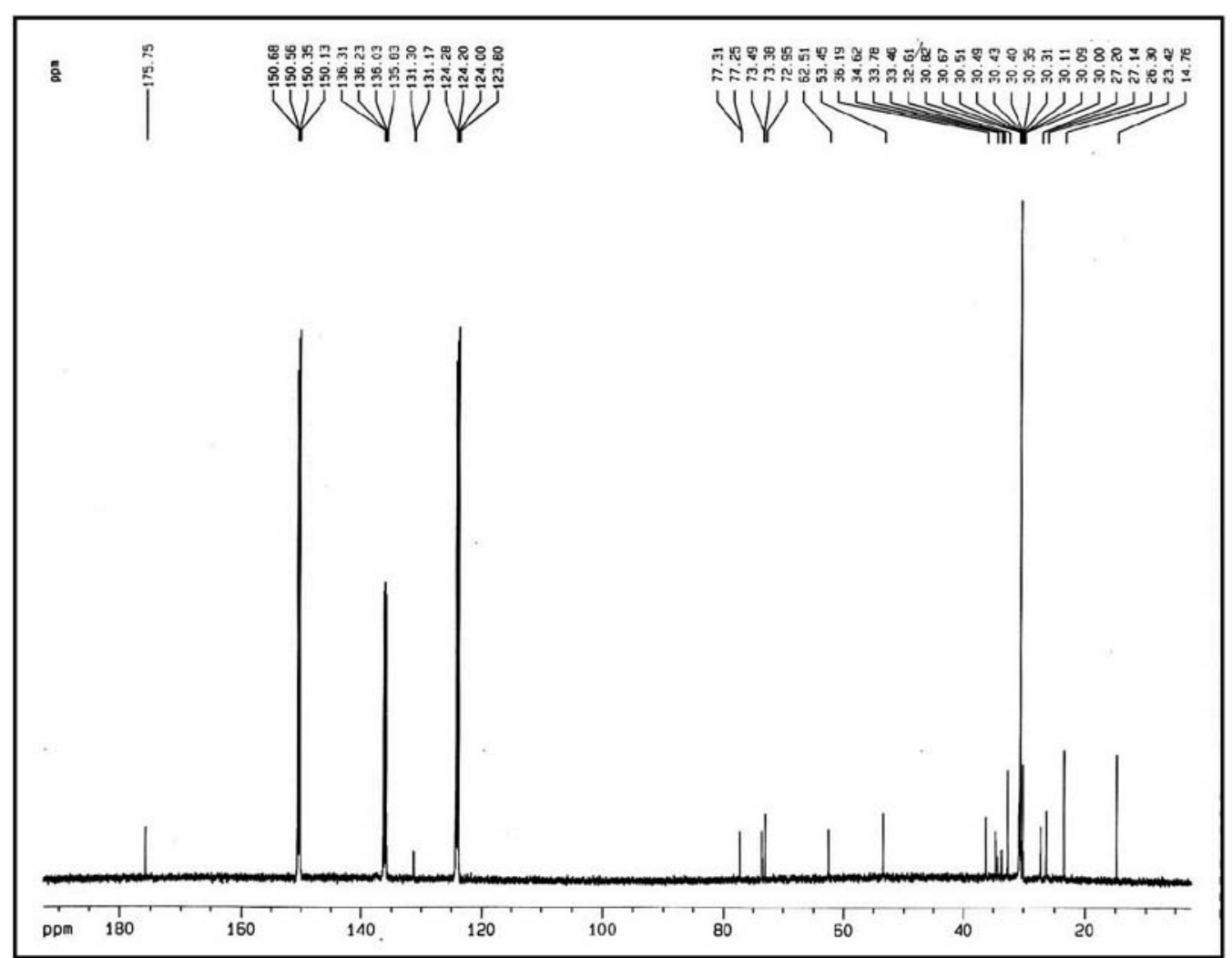

Figure S12. ${ }^{13} \mathrm{C}$ NMR spectrum of compound 2 (pyridine- $d_{5}, 125 \mathrm{MHz}$ ). 


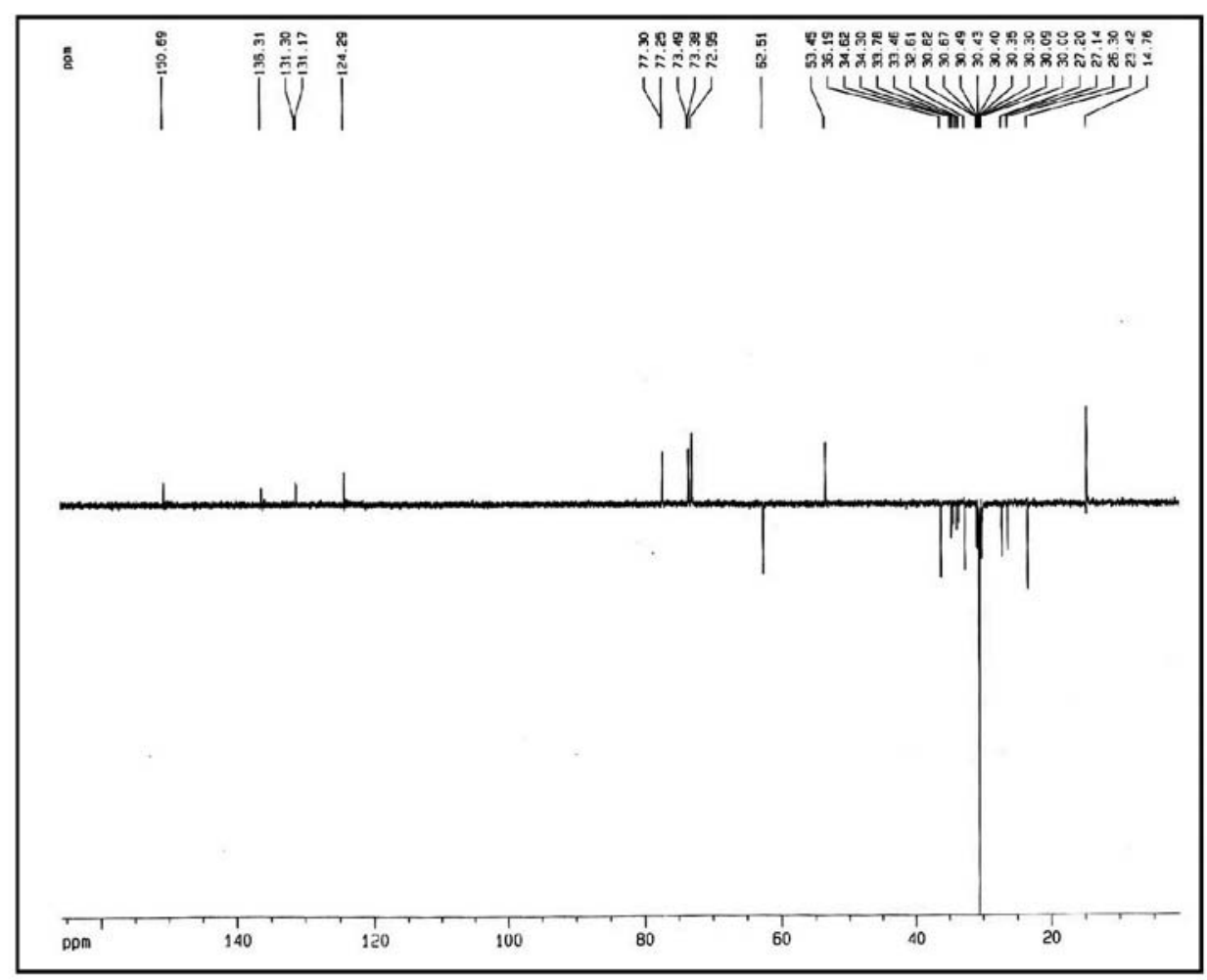

Figure S13. ${ }^{13} \mathrm{C}$ NMR - DEPT spectrum of compound 2 (pyridine- $d_{5}, 125 \mathrm{MHz}$ ).

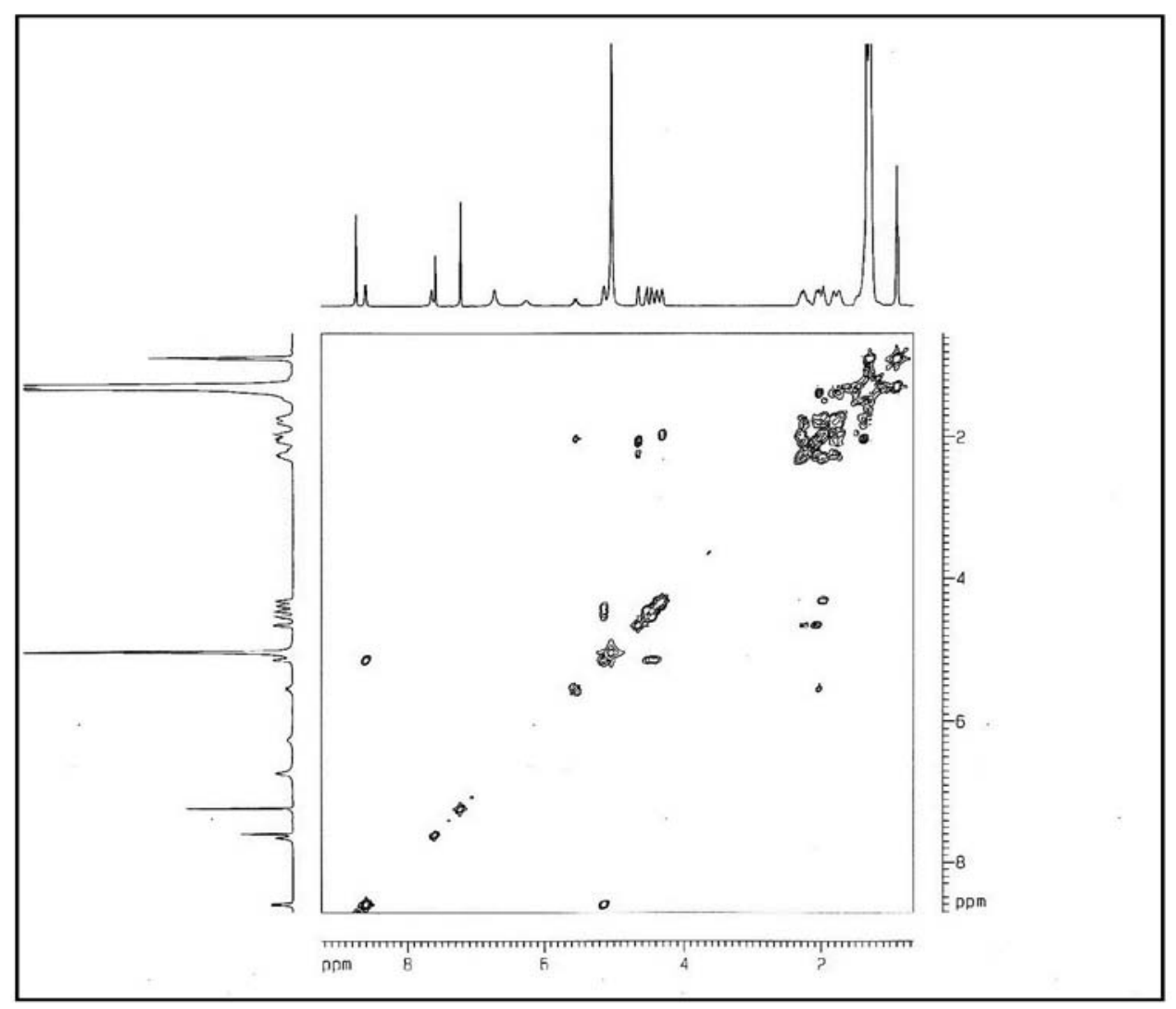

Figure S14. ${ }^{1} \mathrm{H},{ }^{1} \mathrm{H}$ COSY spectrum of compound 2 (pyridine- $d_{5}$ ). 


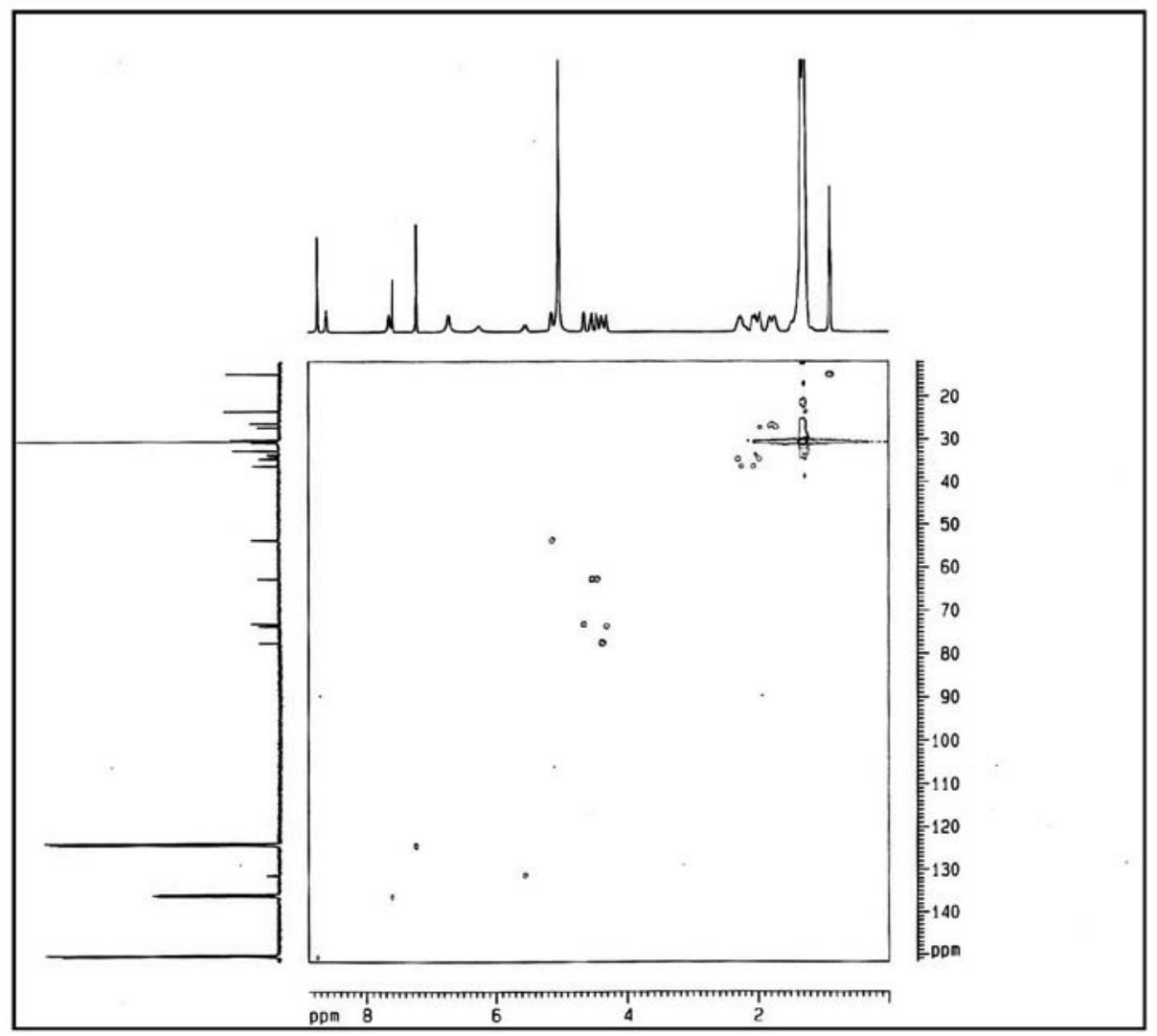

Figure S15. HMQC spectrum of compound 2 (pyridine- $d_{5}$ ).

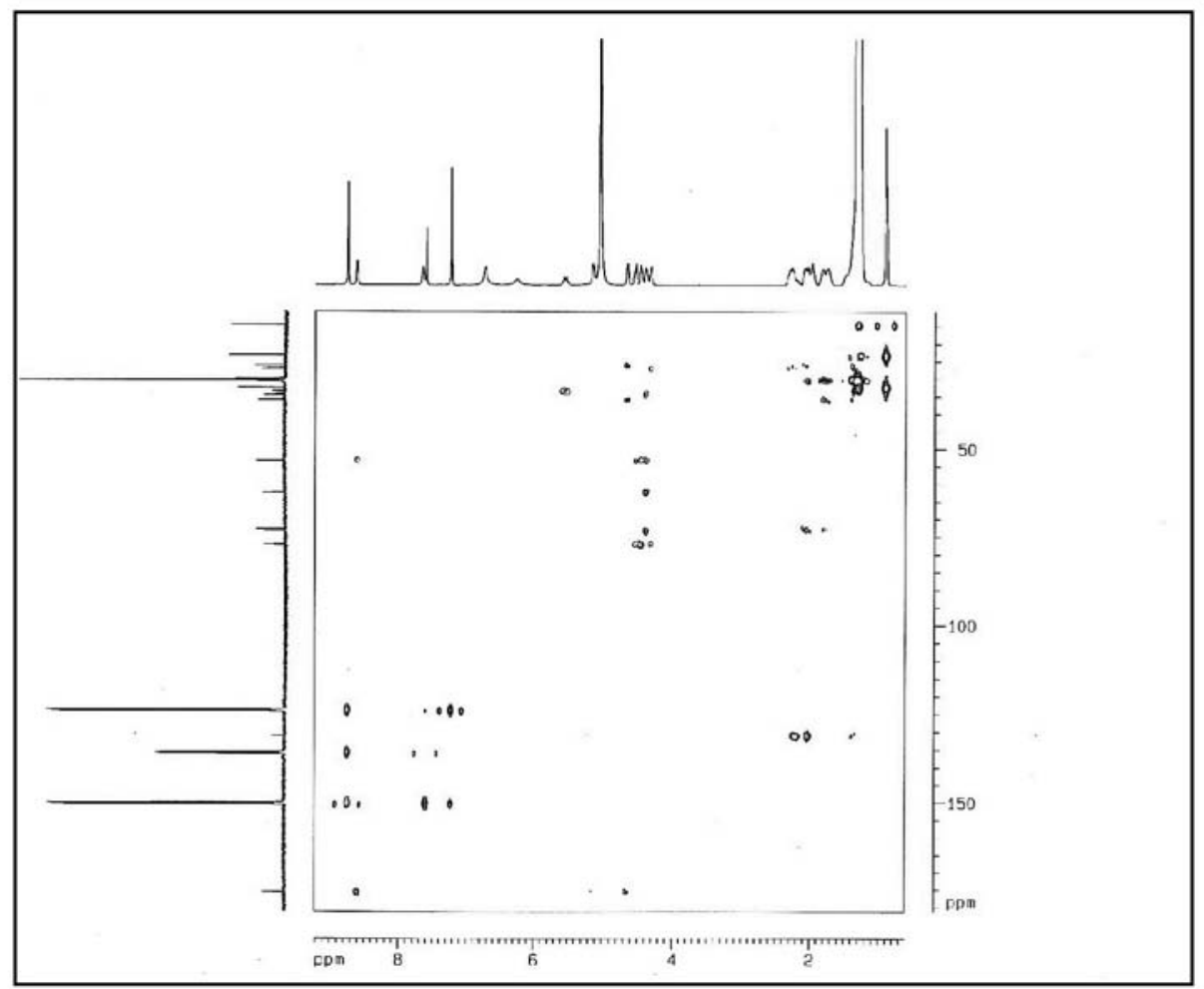

Figure S16. HMBC spectrum of compound 2 (pyridine- $d_{5}$ ). 